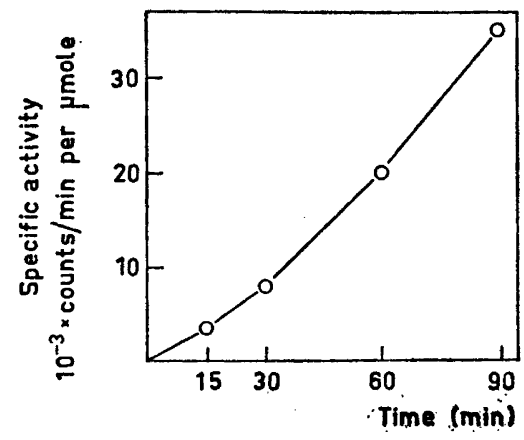

Fig. 4. Formation of spermidine from spermine. Incorporation of radioactivity from spermine${ }^{14} \mathrm{C}$ into spermidine. $0.1 \mu \mathrm{C}(0.024 \mu$ mole $)$ of spermine-1,4. ${ }^{14} \mathrm{C}$ (NEN) was incubated in the presence of ascites cells. Details in Material and methods and in the legend to Fig. 2.

version of spermine to spermidine also seems to be the more rapid reaction.

The physiological function of polyamines, spermidine and spermine is not yet understood. However, we now have increasing evidence of their association with certain cellular components, especially nucleic acids. They exert many stabilizing effects on cellular polyanions and can directly stimulate nucleic acid synthesis in microorganisms. ${ }^{1}$

The occurrence of polyamines and their biosynthetic pathways in rapidly growing cells and tissues suggests that they may play an essential role in cell growth.

1. Tabor, H. and Tabor, C. W. Pharmacol. Rev. 16 (1964) 245.

2. Raina, A. Acta Physiol. Scand. 60 (1963) Suppl. 218.

3. Raina, A. Acta Chem. Scand. 18 (1964) 2188.

4. Morris, D. R. and Pardee, A. B. Biochem. Biophys. Res. Commun. 20 (1965) 697.

5. Morris, D. R. and Pardee, A. B. J. Biol. Chem. 241 (1966) 3129.

6. Jänne, J. Under preparation.

7. Jänne, J. and Raina, A. Acta Chem. Scand. 20 (1966) 1174.

8. Siimes, M. Abstracts 3rd Meeting Federation European Biochem. Soc. Warsaw 1966.

9. Razin, S., Bachrach, U. and Gery, I. Nature 181 (1958) 700.

10. Siimes, M. Acta Physiol. Scand. (1967) Suppl. 298.
11. Jänne, J., Raina, A. and Siimes, M. Acta Physiol. Scand. 62 (1964) 352.

12. Raina, A., Jänne, J. and Siimes, $M$. Abstracts 2nd Meeting Federation European Biochem. Soc. Vienna 1965.

13. Dykstra, W. G. and Herbst, E. J. Science 149 (1965) 428.

14. Raina, A., Jänne, J. and Siimes, $M$. Biochim. Biophys. Acta 123 (1966) 197.

15. Lowry, O. H., Rosebrough, N. J., Farr, A. L. and Randall, R. J. J. Biol. Chem. 193 (1951) 265.

Received February 7, 1967.

\section{Germanium Alkoxides}

Attempt at Synthesis by Photochemical Coupling

\section{K. TAUGBöL, E. AUGDAHL and}

A. N. SARA

\section{Kjemisk Institutt A, Universitetet $i$ Oslo, Blindern, Oslo 3, Norway}

A number of alkoxy-tin compounds have A been prepared earlier by photochemical coupling between tin tetrahalides and simple halogenated aliphatic compounds. Corresponding reactions between germanium tetrahalides and a number of the same organic reactants do not give alkoxides, but germanium dioxide, as a final product.

The reactions were performed in carbon tetrachloride solutions which were saturated with oxygen gas at a pressure of $1 \mathrm{~atm}$. Small amounts of free halogen were added to initiate the reactions. A 125 W mercury-vapour lamp was used as a light source. All reactions were carried out under extremely dry conditions. Constant temperatures were obtained in a thermostated bath.

The different reaction experiments are specified in Table 1.

The germanium dioxide was identified by X-ray powder analysis and by infrared spectroscopic examinations. ${ }^{2}$ The hexagonal modification was found in all cases. All reaction mixtures were filtered and 
Table 1. Experimental conditions.

Reactants

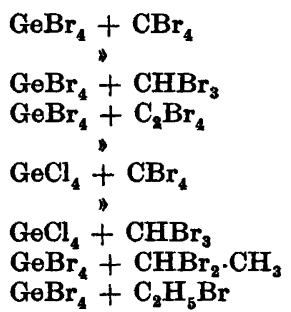

$\begin{array}{cc}\begin{array}{c}\text { Reaction } \\ \text { temperature } \\ { }^{\circ} \mathrm{C}\end{array} & \begin{array}{c}\text { Time } \\ \text { reactio } \\ \text { h }\end{array} \\ & \\ 20 & 3.8 \\ 0 & 8.0 \\ 0 & 1.8 \\ 20 & 4.0 \\ 0 & 4.5 \\ 20 & 3.8 \\ 0 & 3.5 \\ 0 & 14.0 \\ 0 & 15.5 \\ 0 & 22.0\end{array}$

Conc. mole/l Conc. mole/l of $\mathrm{GeX}_{4}$ of organic reactant

Solid reaction products

$\begin{array}{ll}0.064 & 0.066 \\ 0.077 & 0.062 \\ 0.064 & 0.143 \\ 0.064 & 0.060 \\ 0.064 & 0.060 \\ 0.117 & 0.107 \\ 0.117 & 0.121 \\ 0.055 & 0.143 \\ 0.064 & 0.068 \\ 0.077 & 0.162\end{array}$

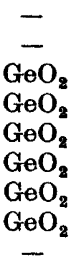

examined by infrared spectroscopy after concentration to small volumes. No coupled products, or at the most only traces, were found. The corresponding reactions with tin tetrahalides gave, except in the cases of 1,1-dibromo-ethane and ethyl bromide, solid reaction products of alkoxy-tin compounds.

However, there is a strong indication of coupling reactions between metal tetrahalides and organic compounds also in the case of germanium. Thus, the formation of germanium dioxide is observed only when an organic reactant of the type which reacts with tin tetrahalides is present. On the other side organic halogen compounds which do not couple with tin tetrahalides, e.g. ethyl bromide and 1,1dibromoethane, yield no germanium dioxide. Infrared spectroscopic examinations of the reaction solutions gave no indications of coupled products. Photo-oxidations of germanium tetrabromide and germanium tetrachloride, respectively, without organic compounds present have been carried out. No germanium dioxide was formed after $13 \mathrm{~h}$ in these cases. Infrared spectra of the reaction solutions showed no, or only very weak, absorption around $870 \mathrm{~cm}^{-1}$, where germanium dioxide has a broad and strong band. ${ }^{2}$

The absence of the reaction between germanium tetrabromide and carbon tetrabromide, as shown in the table, is assumed to be due to a steric effect as the reaction proceeds when germanium tetrachloride is used.

On the basis of these results a coupled molecule of the type $M-O-C$ is suggested as an intermediate in all reactions where germanium dioxide is formed. The $\mathrm{C}-\mathrm{O}$ bond is subsequently broken. The average dissociation energies of the $\mathbf{M}-\mathrm{O}$ bonds for the elements in the IV $A$ group are decreasing in the following order: $\mathrm{Si}>\mathrm{Ge}>$ $\mathrm{Sn}>\mathrm{Pb}>\mathrm{C}$. The value for germanium is about $150 \mathrm{kcal} / \mathrm{mole}$ as compared to ca. $130 \mathrm{kcal} / \mathrm{mole}$ for tin. The reason may be contributions from $\mathrm{d} \pi-\mathrm{p} \pi$ bonds.

The relationship between a strong $\mathrm{M}-\mathrm{O}$ bond and a weak $\mathrm{C}-\mathrm{O}$ bond in metal alkoxides has been reported by different authors. Kawasaki et al. ${ }^{3}$ have shown by infrared spectroscopic measurements of alkoxybridged tin complexes that electronegative substituents on tin strengthen the $\mathrm{Sn}-\mathrm{O}$ bond and weaken the $\mathrm{C}-\mathrm{O}$ bond. Other workers have shown a similar correlation in oxalato complexes between strong $\mathrm{M}-\mathrm{O}$ bonds and weak $\mathrm{C}-\mathrm{O}$ bonds. With increasing electronegativity of the bivalent transition metal the $\mathrm{C}-\mathrm{O}$ bond becomes weaker.

The confirmation of a weak $\mathrm{C}-\mathrm{O}$ linkage in the germanium alkoxides could not be obtained from infrared data as very little work has been published on this type of compounds. The spectra of 7 alkoxygermanes have been reported, ${ }^{5}$ but no assignments have been given for the $\mathrm{C}-\mathrm{O}-\mathrm{G}_{\theta}$ vibrations.

The difference in the stability of the germanium and tin compounds may also have a coherence with the smaller ability of germanium to attain a higher coordination number than four.

Acknowledgement. We are grateful to Norges almenvitenskapelige forskningsråd for financial support. 
1. Taugböl, K., Augdahl, E. and Sara, A. N. Acta Chem. Scand. 21 (1967) 505.

2. Shaw, E. R., Corwin, J. F. and Knorr, H. V. J. Phys. Chem. 64 (1960) 174.

3. Kawasaki, Y., Tanaka, T. and Okawara, R. J. Organometal Chem. 6 (1966) 95.

4. Nakamoto, K. Infrared Spectra of Inorganic and Coordination Compounds, Wiley, New York, London 1963, p. 214.

5. Johnson, O. H. and Fritz, H. E. J. Am. Chem. Soc. 75 (1953) 718.

Received February 3, 1967.

\section{On the Hydrolysis of the Tetrachloroaurate(III) Ion} LENA CARLSSON and GEORG LUNDGREN

Department of Inorganic Chemistry, Chalmers Institute of Technology and University of Gothenburg, Gibraltargatan 5A, Gothenburg $S$, Sweden

$A^{s}$ s part of a series of investigations of gold(III) complexes in aqueous solutions, the equilibria between $\mathrm{AuCl}_{4}^{-}$and $\mathrm{OH}^{-}$in sodium perchlorate medium have been studied. The experiments were carried out as emf titrations at a constant ionic strength of $3 \mathbf{M}$, and for each titration the total concentrations of gold and chloride ions were kept constant. They varied from $5 \times 10^{-3}$ to $100 \times 10^{-3} \mathrm{M}$ for gold, and from $21 \times 10^{-3}$ to $410 \times 10^{-8} \mathrm{M}$ for chloride ions. The emf values were measured with a Radiometer PHM 4 potentio. meter, using a glass electrode, calibrated regularly against a hydrogen gas electrode. The measurements were performed in the pH range $1.0 \leq \mathrm{pH} \leq 6.5$. The points obtained from a titration and from a back titration for identical total concentrations of gold and chloride both fell on the same curve.

The experimental points all fell on very smooth curves, when plotted as $Z=\mathbf{f}(\log$ $h$ ), where $Z$ is the average number of $\mathrm{OH}^{-}$ bound to each $\mathrm{Au}$ in the solutions.

A preliminary analysis of the experimental data using a "curve-fitting" method, very similar to those published by Sillén," showed that the equilibria in the solutions could be explained by the formation of $\mathrm{AuCl}_{4}^{-}, \mathrm{AuCl}_{3}\left(\mathrm{H}_{2} \mathrm{O}\right), \mathrm{AuCl}_{3}(\mathrm{OH})^{-}$, and $\mathrm{AuCl}_{2}(\mathrm{OH})_{2}^{-}$. At higher $Z$ values, the species $\mathrm{AuCl}(\mathrm{OH})_{3}^{-}$and $\mathrm{Au}(\mathrm{OH})_{4}^{-}$are probably also present. This is in good agreement with previous results obtained by Bjerrum ${ }^{2}$ who showed the existence of the ions $\mathrm{AuCl}_{n}(\mathrm{OH})_{4-n^{-}}$where $n=$ $0,1,2,3,4$.

The preliminary constants obtained for the following two reactions

$$
\begin{aligned}
& \mathrm{AuCl}_{4}^{-}+\mathrm{H}_{2} \mathrm{O} \rightleftharpoons \mathrm{Au}(\mathrm{OH}) \mathrm{Cl}_{3}^{-}+\mathrm{H}^{+}+ \\
& \mathrm{CuCl}_{4}^{-}+2 \mathrm{H}_{2} \mathrm{O} \rightleftharpoons \mathrm{Au}(\mathrm{OH})_{2} \mathrm{Cl}_{2}^{-}+2 \mathrm{H}^{+} \\
& \quad+2 \mathrm{Cl}^{-}
\end{aligned}
$$

are $\beta_{1}=10^{-6.22} \mathrm{M}^{2}$ and $\beta_{2}=10^{-13.26} \mathrm{M}^{4}$, which are very close to those obtained by Bjerrum. $^{2}$

In addition, the equilibrium constant for the reaction $\mathrm{Au}(\mathrm{OH}) \mathrm{Cl}_{3}^{-}+\mathrm{H}^{+} \rightleftharpoons$ $\mathrm{Au}\left(\mathrm{H}_{2} \mathrm{O}\right) \mathrm{Cl}_{3}$ has been found to be $10^{2} .{ }^{72} \mathrm{M}^{-1}$. This complex was not considered by Bjerrum, ${ }^{2}$ but Fry et al. ${ }^{3}$ recently assumed the existence of a species $\mathrm{Au}\left(\mathrm{H}_{2} \mathrm{O}\right) \mathrm{Cl}_{3}$ to explain their kinetic experiments on the aqueous hydrolysis of $\mathrm{AuCl}_{4}^{-}$. They were not able, however, to determine any equilibrium constant from their measurements.

Refinement of the experimental data by computer methods is now in progress, and the results will soon be published in this journal.

The authors are indebted to the Swedish Natural Science Research Council, which has supported this work under Contract No. 2318.

1. Sillén, L. G. Acta Chem. Scand. 8 (1954) 299 , 318.

2. Bjerrum, N. Bull. Soc. Chim. Belges 57 (1948) 432.

3. Fry, F. H., Hamilton, G. A. and Turkevich, J. Inorg. Chem. 5 (1966) 1943.

Received February 28, 1967. 